\title{
Exploration and Exploitation in Latin American Firms: The Determinants of Organizational Ambidexterity and The Country Effect
}

\author{
Juan Acevedo ${ }^{1 *}$, Iván Díaz-Molina ${ }^{1}$
}

\begin{abstract}
In this article, we explore the determinants of organizational ambidexterity across Latin American countries -Chile, Ecuador, and Peru- from innovation surveys of 2,786 manufacturing companies. The study introduces valuable information on ambidextrous organizations in emerging economies, contrasting to traditional literature frequently focusing on developed countries. Findings confirm the importance to measure ambidexterity in a multidimensional perspective, relating exploration to radical innovation, and breaking down exploitation into incremental exploitation, related to incremental innovation and repetitive exploitation related to operational efficiency. This work also finds that higher GDP per capita relates to higher exploration and exploitation ability of firms and supported our hypotheses that political and economic uncertainty of each country impact on organizational ambidexterity. Additionally, we expand on Diaz-Molina's model (2018), on the relationship between strategic and operational absorptive capacity on ambidexterity by validating his findings across several countries and uncovering a positive interaction term between strategic and operational absorptive capacity when both impact on ambidexterity.
\end{abstract}

Keywords: ambidexterity; innovation; absorptive capacity; country environment; emerging economies

Submitted: August 30 $0^{\text {th }}, 2019 /$ Approved: November $6^{\text {th }}, 2019$

\section{Introduction}

As some studies suggest, the actual objective of companies is to remain competitive and to thrive in the long-term, and this purpose is possible when organizations become ambidextrous (Levinthal and March 1993; March 1991). In other words, firms should focus on their ability to exploit their current capabilities while simultaneously exploring fundamentally new competencies.

Concepts of "exploration" and "exploitation" have increasingly dominated organizational analyses of technological innovation, organizational adaptation, or organizational learning. Studies have identified many antecedents to ambidextrous firms in developed countries (Piao and Zajac,2016; Jansen et al., 2009; Lederman, 2010); however, little research has examined the Latin-American context.

Accordingly, the primary purpose of this article is to analyze the determinants of organizational ambidexterity in emerging economies, specifically, companies from Latin American countries - Chile, Ecuador, and Peru-.

This paper examines the effect of the country-specific environment on the development of ambidextrous organizations. According to Crespi \& Zuñiga (2012), determinants of innovation are not the same across countries; in other words, there is a diversity of innovative behavior among countries in Latin America. Simsek (2009) argues that environmental factors might exert influences on ambidextrous firms; for this reason, companies 'strategy include external contingencies.

Validating the concept of organizational ambidexterity as a threedimensional construct as proposed by Piao \& Zajac (Piao \& Zajac, 2016); we find that Latin-American companies are better-off implementing organizational ambidexterity practices through exploration (radical innovation), incremental exploitation (incremental innovation) and repetitive exploitation (operational efficiency).

Additionally, the present study contributes to filling a gap in the literature on the direct effect of country-specific characteristics in organizational ambidexterity. Controlling by GDP per capita, there is evidence to suggest that ambidexterity is more spread in countries with better economic situation.

Finally, we expand on Diaz-Molina's model (2018), on the relationship between strategic and operational absorptive capacity on ambidexterity by validating his findings across several countries and uncovering a positive interaction term between strategic and operational absorptive capacity when both impact on ambidexterity.

The rest of the paper is structured as follows, the second section provides a brief overview of the literature and develops hypotheses on organizational ambidexterity. The third section outlines the methodology used for the study and provides sample descriptive statistics. Next, the econometric results of the study are presented along with a discussion, conclusions and contributions.

\section{Literature Review and Hypotheses}

2.1 Exploration and exploitation in organizational ambidexterity Generally, an ambidextrous organization is defined as "the ability of an organization to both explore and exploit with the aim of competing in mature technologies and markets where efficiency, control, and incremental improvement are prized and to also compete in new technologies and markets where flexibility, autonomy, and experimentation are needed" (O’Reilly and Tushman, 2013, p. 324).

1) Centro de Innovación y Emprendimiento, ESE Business School, Universidad de Los Andes

${ }^{*}$ Corresponding author: jacevedo.ese@uandes.cl 
According to this definition, the relation between exploration and exploitation is the crucial characteristics of ambidexterity. Exploration/Exploitation dichotomy has been associated with different organizational dimensions. The term of exploration is commonly related to the acquisition of new knowledge through learning and innovation. Meanwhile, the term of exploitation refers to the use of prior knowledge for searching efficiency (Gupta, Smith, \& Shalley, 2006).

On product innovation, Piao and Zajac (2016) define exploitation as the repetition and incremental refinement of a firm's existing products aimed at improving existing product-market domains. Meanwhile, exploration is the development of new products aimed at entering new product-market domains in terms of knowledge. Vermeulen and Barkema (2001) linked exploration as the search for new knowledge and exploitation as the continuing use of a firm's past knowledge base.

Several studies suggest that ambidexterity is positively associated with firm performance, specifically sales growth (O'Reilly and Tushman, 2013; Auh \& Menguc, 2005; Han \& Celly, 2008; Venkatraman et al., 2006). For this reason, a main area of research has been to identify the requirements to balance the tension between exploration and exploitation, a central issue of ambidextrous organizations.

According to this, the current research recognizes different ways to achieve ambidexterity. One mechanism is known as "sequential ambidexterity" which proposes sequencing changes in the structure to promote temporary periods of exploring and exploiting (Siggelkow and Levinthal, 2003). Another mechanism is "architectural ambidexterity" related to a dual organizational structure where simultaneously some units would be specialized in explorations and others in exploitation; each unit has a different process, culture, and dynamics (O’Reilly and Tushman 2008). Finally, an individual dimension to manage this tension is known as "contextual ambidexterity," which is referred to as the ability to deploy alignment—exploitation-as well as adaptability—exploration — throughout a business unit, requiring organizational support and individuals able to make judgments about alignment and adaptability simultaneously(Gibson and Birkinshaw, 2004).

Nevertheless, O'Reilly and Tushman (2013) analyzed different studies to conclude that these modes of ambidexterity are potentially viable and complementary. Indeed, firms may use combinations of sequential, architectural, or contextual ambidexterity according to the nature of the market faced. The key is to determine the rates of exploration and exploitation required over time,

Piao and Zajac (2016) recognized exploitation that could impel exploration. Additionally, the authors introduced three dimensions of organizational ambidexterity: exploration, incremental exploitation, and repetitive exploration. "Incremental exploitation" is the creation of new designs for existing products, and "repetitive exploitation" is the repetition of existing designs for existing products that could potentially impede exploration. For the objectives of this article, the approach proposed by Piao and Zajac is used to measure ambidexterity.

\subsection{Innovative behavior among Latin American and developed economies}

Most studies about organizational ambidexterity and innovation have focused on developed economies with less emphasis on emerging markets such as Latin America, representing a gap in the systematic investigation of these constructs process (Heredia Pérez et al., 2019).

Studies have shown that in comparison with other regions, the economic growth of Latin America has been unsatisfactory with stagnant productivity levels being the most urgent challenge (Crespi et. al., 2017; Álvarez and Grazzi, 2018; Zahler et al., 2018). Consequently, these studies have suggested the importance of innovation to improve productivity, applying technological advances to lead more effective use of productive resources, and the transformation of new ideas into new economic solutions (Crespi and Zuñiga, 2012).

Extant research identifies informality in the innovation process, focus on imitation and technology acquisition rather than $\mathrm{R} \& \mathrm{D}$, fewer resources devoted to innovation activities, and fragmented flows of information within national systems of innovation as the main differences between Latin America and developed countries' innovation practices (Crespi and Zuñiga, 2012; Heredia Pérez et al, 2019; Geldes et al., 2017)..

These different practices and the fact that innovation performance increases faster in developed economies warrants a more detailed view of organizational ambidexterity in Latin America. (Lee, Özsomer,\& Zhou, 2015).

\subsection{The impact of the country environment on organizational ambidexterity}

The extent to which environment determines organizational ambidexterity remains poorly understood. Simsek (2009) postulates a multilevel model of organizational ambidexterity, where environmental factors moderate the effect of ambidexterity on firm performance. The author proposes that an organization's strategy can be designed in terms of its fit or congruence with the environmental contingencies facing the organization.

For example, in environments with little dynamism, the need to introduce new innovations is not necessary for enhancing performance because the organization might benefit more by being exploitative. In contrast, organizations in dynamic environments must be strategically flexible and efficient because customers need, and competitor activities demand, immediate action (Sidhu et al., 2004).

Regarding the environment's aspects, Jansen et al. (2006), indicated that pursuing exploratory innovation is more effective in dynamic environments, whereas pursuing exploitative innovation is more beneficial in more competitive environments. Patel et al. (2012) reported that ambidexterity is mediating the relationship between environmental uncertainty and firm performance. As a result, ambidextrous companies are more likely to be able to both refine existing resources and develop new competencies in an uncertain environment. Meanwhile, firms that lack ambidexterity are less likely to respond effectively to environmental demands. 
Crespi \& Zuñiga (2012) report that determinants of innovation are not the same across countries, showing the diversity of innovative behavior. Exploitation - related to process innovation- is more frequent than exploration -related to product innovation-, due to the preponderance of capital goods and machinery in innovation investment. Additionally, it is important to recognize that environments in Latin American region differ between countries and; for instance, countries like Argentina, Chile and Uruguay, with active innovation policies have better results in innovation rate than other countries in the region. In emerging economies, firms adjust strategies to the dynamic external environment to remain competitive by balancing exploration and exploitation activities (Heredia Pérez et al.,2019).

An interesting element in the debate is the impact on innovation of some political and economic uncertainties due to some Latin America's faulty institutions. Geldes et al. (2017) concluded that companies use diverse strategies such as interpersonal ties, networking and partnership alliances and review the firm's boundaries to deal with uncertain environments.

Accordingly, one of the objectives of this article is to analyze the effect of country environment on organizational ambidexterity. Studies focusing on ambidextrous organizations have failed to explain the role of country-specific characteristics in this phenomenon, especially their direct effect. Companies face contingencies specific to each country, which develop uncertain or stable conditions to define firms' strategies for their exploitation and exploration activities.

Considering that $\mathrm{R} \& \mathrm{D}$ spending, innovation, productivity, and per capita income reinforce each other, sustaining long-term growth (Hall and Jones 1999; Rouvinen 2002), we postulate that countries with better economic situation, using GDP per capita as proxy, generate better conditions to develop ambidextrous organizations. Accordingly, the hypotheses to be tested are:

H1. Better country's economic situation increases the exploratory component of organizational ambidexterity.

H2. Better country's economic situation increases the exploitative component of organizational ambidexterity.

Additionally, we postulate that political and economic uncertainty impact organizational ambidexterity.

H3. Higher country's political and economic uncertainty decreases the exploratory component of organizational ambidexterity.

H4. Higher country's political and economic uncertainty decreases the exploitative component of organizational ambidexterity.

\subsection{The impact of absorptive capacity on organizational ambidexterity}

Another objective of this paper is to expand on prior research on the relationship between absorptive capacity and ambidexterity (DiazMolina,2018). Absorptive capacity is the ability of a firm to recognize, assimilate, and apply new knowledge, and it is considered paramount since new competitive advantages will very likely come from outside sources (Cohen \& Levinthal, 1989; 1990). The original work by Diaz-Molina was tested only on Chilean firms, we contribute to the validity of the model by diversifying the source of firms including three additional countries.

Regarding a strategic dimension, absorptive capacity is observed as strategic learning, improving the innovation performance of the firm (Lin et al.,2016). Therefore, using and integrating external knowledge, a firm could acquire a competitive advantage in new products and markets, in other words, in exploration (Chen et al., 2011; Lin et al., 2016). Moreover, in the case of incremental innovation, Diaz-Molina (2018) proposed that external knowledge is used for the creation of new designs for existing products. According to Lichtenthaler (2009), technological knowledge is the knowledge the firm explores, but also exploits, identifying application and commercialization opportunities. Consequently, we can formulate the following hypotheses:

H5. Higher strategic absorptive capacity increases the exploratory component of organizational ambidexterity

H6. Higher strategic absorptive capacity increases the exploitative component of organizational ambidexterity.

Regarding operational dimension, absorptive capacity is observed as the skill of a firm's internal units to acquire, assimilate, and transform external information. Patel et al. (2012) suggested that operational absorptive capacity can influence the firm's ability to rapidly analyze and act on changes to the operational environment like changes in demand and quickly increasing the range and mobility of machines, labor, and material. Therefore, companies could understand how to perform innovation on new products and processes implementation, which is closely associated to exploration and exploitation activities. Consequently, we expect that:

H7. Higher operational absorptive capacity increases the exploratory component of organizational ambidexterity.

H8. Higher operational absorptive capacity increases the exploitative component of organizational ambidexterity.

Finally, another aspect understudied has been the complementary relation between strategic and operational absorptive capacity, when both capabilities impact the organizational ambidexterity of companies. Some studies have reported that not only external but also internal dimension of absorptive capacity are complementary, interrelated, and necessary (Zahra and George, 2002; Harris and Lee, 2018; Chesbrough, 2005). For this reason, it is possible to infer that acquisition and assimilation of external knowledge are influenced by internal units of company that transform this kind of information. In turn, the development of these internal units is conditioned by the scope of external sources that support innovative activities.

H9. There is a potential complementary effect between strategic and operational absorptive capacity when both impact on the organizational ambidexterity. 


\section{Methodology}

\subsection{Data}

Regarding the objectives of this research, we conducted an exploratory quantitative study based on secondary data available from three Latin American countries: Chile, Peru, and Ecuador. We used the National Innovation Survey of each country, which is performed at the firm level, follows the OECD guidelines included in the Oslo Manual (Organisation for Economic Co-operation and Development, 1997).

One of the values of this study has been the collection of data compatible and comparable across countries. For this purpose, the OECD guidelines included in the Oslo Manual was a relevant help, because countries -given certain limitations- used the similar sampling methodologies, questionnaire design, and data processing.

The dataset includes data from the 2014-2016 period. Our analysis only covers manufacturing companies, achieving a final sample of 2,786 companies, made up of 1,439 companies from Peru, 950 companies from Ecuador and 397 companies from Chile.

\subsection{Dependent Variables}

Based on Diaz-Molina (2018) and Piao \& Zajac (2016), we considered organizational ambidexterity as a multidimensional concept with three dimensions to measure: exploration, incremental exploitation, and repetitive exploitation. The exploratory function of ambidexterity is measured by identifying the product innovation of the firm. According to OECD guidelines, product innovation is the introduction to the market of a new good or service, or a significantly improved good or service, regarding its characteristics or its use. In this study, we used two dichotomic questions to measure exploration: If the company is succeeded in introducing new goods to the market (Yes/ No) or if the company is succeeded in introducing new services to the market (Yes/No). Thus, a polychoric procedure was conducted before the factor analysis. The results were rotated for a better fit, and the factor is found to be representative. Table 1 summarizes the resulting loadings for the relevant factor. Exploration is represented by one underlying factor encompassing $201 \%$ of the total variance.

Incremental exploitation is measured by identifying the marketing innovation of the firm. According to OECD guidelines, marketing innovation is the introduction to the market of significant changes in product design or packaging, product placement, product promotion, or pricing. In this study, we used four dichotomic questions to measure incremental exploitation: If the company is succeeded in introducing significant changes in i) the design or packaging; ii) advertising; iii) distribution; or iv) pricing. Factor analysis is conducted on these four dichotomous variables using the same methodology as before. One factor is found to be representative (i.e., eigenvalue greater than 1.0) explaining $109 \%$ of the variability and is defined as incremental exploitation.

Repetitive exploitation is represented by five questions covering process innovation (improvements in manufacturing and logistics methods) and organizational innovation (introduction of decision making, external relations, and process design practices). Factor analysis is conducted on these five dichotomous variables using the same methodology as before. One factor with an eigenvalue higher than one were retained explaining $105 \%$ of the variability.

\subsection{Theoretical Variables}

Strategic absorptive capacity was derived from a factor analysis conducted on a set of questions from the survey addressing the external sources firms reach out to for purposes of their innovation activities (Díaz-Molina, 2018). The external sources are classified as market (i.e., suppliers, customers, competitors, and consultants), institutional sources (i.e., universities and research facilities), and others (i.e., conferences, publications, professional associations, and the internet). Answers to these ten questions were dichotomous (YES/NO). Thus, a polychoric procedure was conducted before the factor analysis. The results were rotated for a better fit, and the factors with an eigenvalue higher than 1.0 were retained covering $91 \%$ of the total variance.

Operational absorptive capacity is defined as the ability of the firm to reach outside its boundaries for operational knowledge (i.e., engineering, operational, information systems). Since an innovation survey is the source of the data utilized, no direct question is related to this type of knowledge. A proxy is used following Setia \& Patel (Setia \& Patel, 2013), by assuming that the firm has established engineering and information systems departments and that these departments would reach out for the state-of-the-art practices in each area in order to improve operations. Again, three questions with dichotomous answers are used in the questionnaire to cover this area. The same procedure as the one used for strategic absorptive capacity is used to determine the relevant factors. One factor recorded an eigenvalue higher than 1.0 , covering $125 \%$ of the total variance. Table 1 summarizes the resulting loadings for the relevant factor.

Studies show a virtuous circle in which R\&D spending, innovation, productivity, and per capita income mutually reinforce each other and lead to long-term, sustained growth rates (Hall and Jones 1999; Rouvinen 2002). Therefore, to measure the impact of the country environment on organizational ambidexterity, we use GDP per capita as scalar variable related to the economic situation of each country. The mean of the three analyzed countries is 14.7 dollars. Additionally, we used dummies for each country.

\subsection{Control Variables}

Potential confounding effects were controlled by including various relevant sets of dichotomic variables. Training is considered as an essential capability for the assimilation of knowledge, particularly in the international arena (Lane, Salk, \& Lyles, 2001). The variable cooperation those companies that innovated in collaboration with other entities. Additionally, included exportation as dummy variable if the companies declared exportation activities or not. Other two dummy variables are introduced in the model: internal sources of information; and acquisition of equipment, machinery or software. To account for firm size, we included the natural logarithm of the number of employees. 


\subsection{Statistical Methods}

A multivariate regression model is used to analyze the relationship between strategic absorptive capacity, operational absorptive capacity and country variables (i.e., the independent variables) and exploration, incremental exploitation, and repetitive exploitation (i.e., the dependent variables). A multiple analysis of variance test is performed before the multivariate regression model to test whether or not the independent grouping variable simultaneously explains a statistically significant amount of variance in the dependent variables. The Wilk's Lambda U test, the Lawley-Hotelling test, the Pillai test, and Roy's Largest Root test are performed.

As mentioned above, factor analyses have been conducted using the polychoric correlation matrix in all cases since the underlying variables were all dichotomous (Netter, Wasserman, \& Kutner, 1990).

Table 1. Factor Analysis for Two Independent Variables and Three Dependent Variables

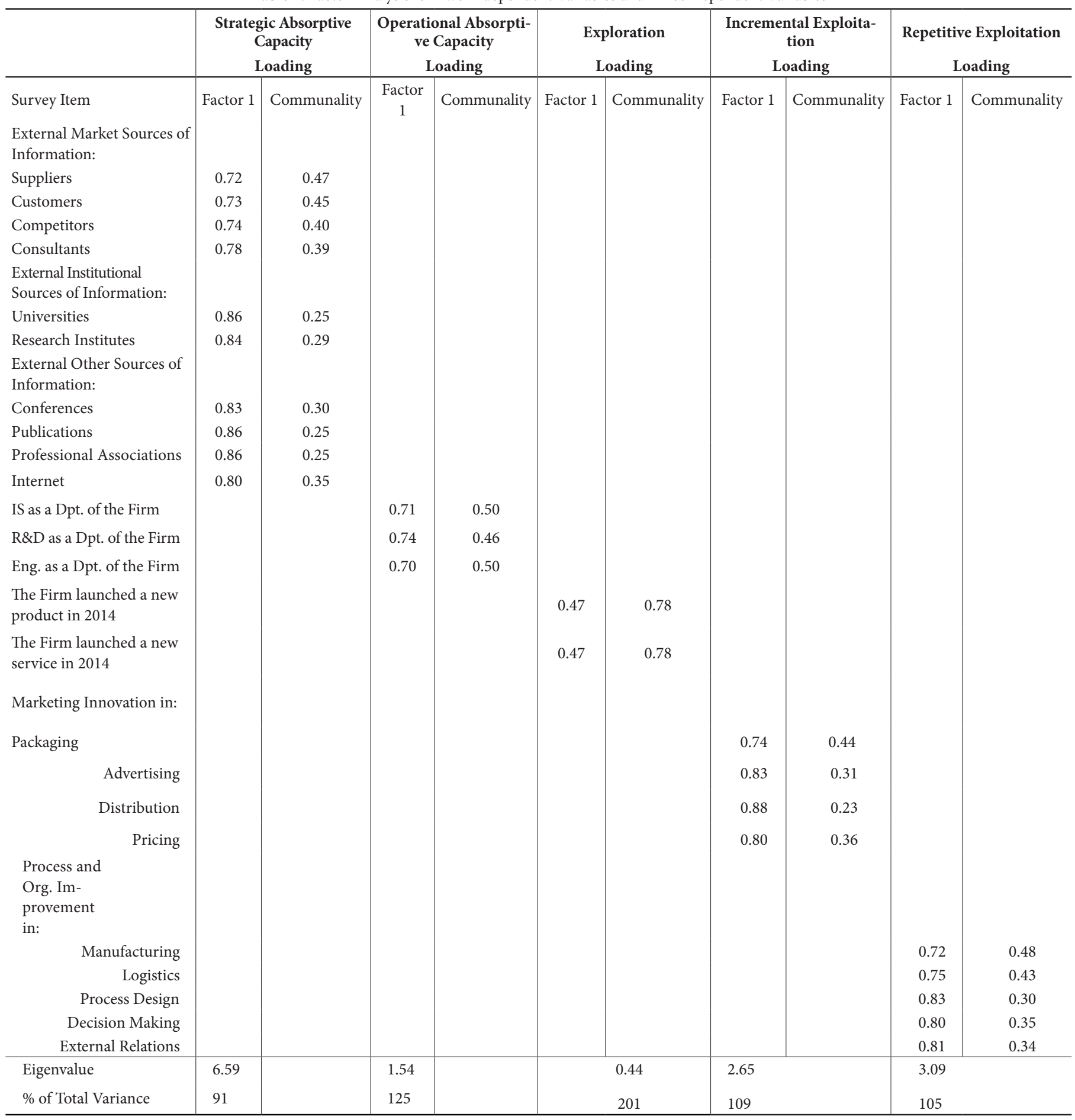




\section{Results}

Table 2 presents descriptive statistics and correlations for the study variables. Table 3 presents the results of the regression analyses for organizational ambidexterity -exploration, incremental exploitation, and repetitive exploitation-. To evaluate heteroscedasticity and multicollinearity on the model, a run was performed with robust standard errors, variance inflation factors were below 5 , and tolerance value was higher than 0.1 ; hence, it was assumed that it was viable to use the aforementioned variables in the analysis (Field, 2013). Moreover, predictor variables are not highly correlated.

Table 2. Descriptive Statistics and Correlation Matrix

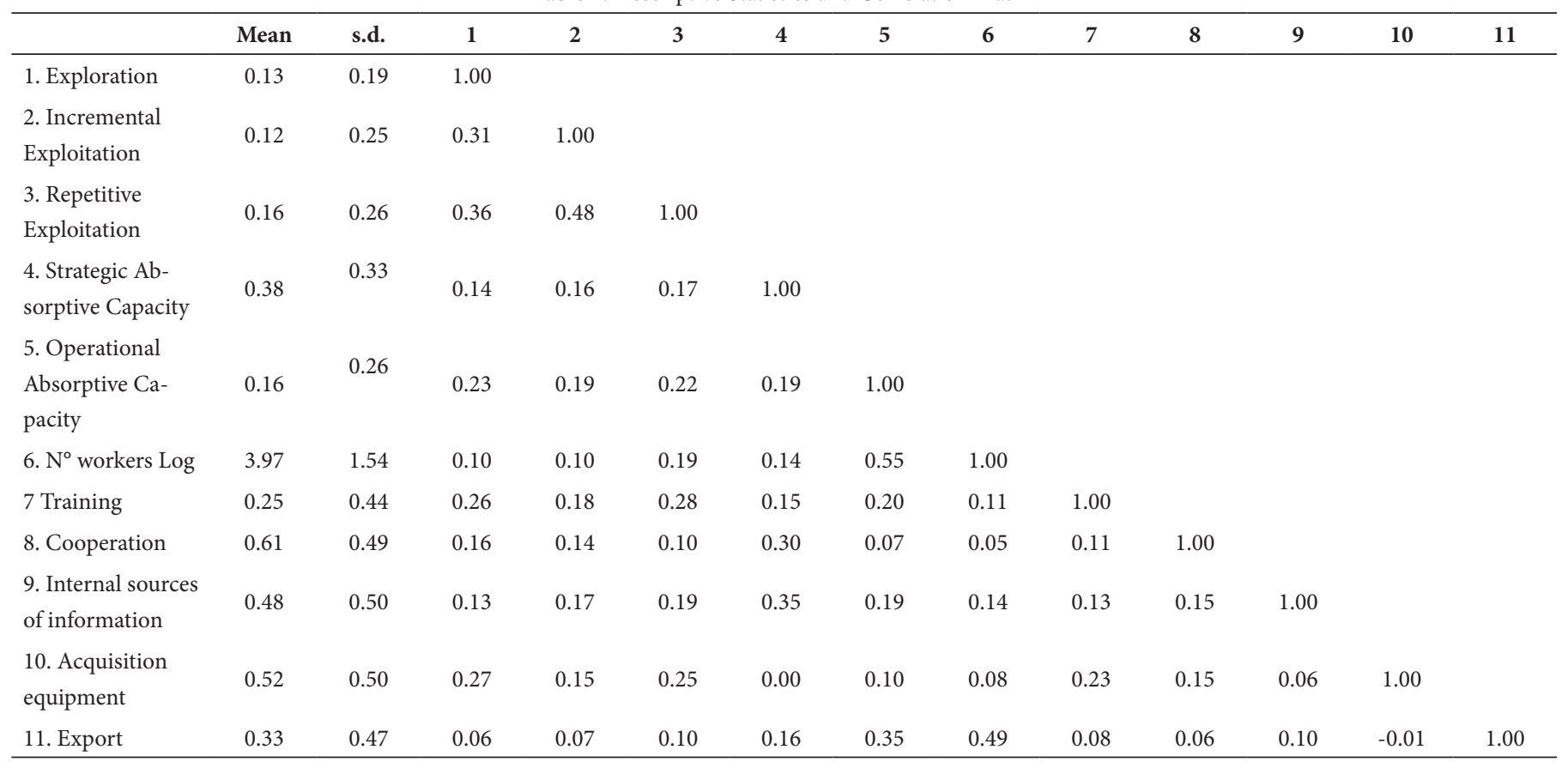

Source: National Innovation Survey of Chile (Décima Encuesta de Innovación de empresas 2015-2016. Ministerio de Economía, Fomento y Turismo); Peru (Encuesta nacional de innovación en la Industria manufacturera 2015. Instituto Nacional de Estadísticas e Informática; Ecuador (Encuesta nacional de actividades de innovación 2015. Instituto Nacional de Estadísticas y Censos).

The baseline model (Model 1 for the three dependent variables) includes control and absorptive capacity variables. Model 2 includes the interaction term between strategic and operational absorptive capacity on the organizational ambidexterity; meanwhile, Model 3 adds the impact of GDP per capita and Model 4 adds dummies for countries -Peru and Ecuador-. Performing a likelihood ratio test (LRT) for each model, results indicate a statistically significant improvement in model fit.

In model 1, it is possible to observe that the coefficients for strategic and operational absorptive capacity are positive and significant for the dependent variables. Strategic absorptive capacity has direct effect on exploration $(\beta=0.03, \mathrm{p}<0.01)$, incremental exploitation $(\beta=0.06$, $\mathrm{p}<0.01)$ and repetitive exploitation $(\beta=0.07, \mathrm{p}<0.01)$. Operational absorptive capacity has a stronger effect on these variables $(\beta=0.12$ on exploration and incremental exploitation; $\beta=0.08$ on repetitive exploitation) at the 0.01 level. Hence, the influence of absorptive capacity is stronger on exploitation than exploration.

In model 2 , there is a positive interaction term between strategic and operational absorptive when both impact on incremental exploitation $(\beta$ $=0.14, \mathrm{p}<0.01)$ and repetitive exploitation $(\beta=0.07, \mathrm{p}<0.05)$; additionally, the effects on exploration is less stronger $(\beta=0.05, \mathrm{p}<0.1)$.
In model 3, results indicate a positive and significant effect of GDP per capita on exploration $(\beta=0.003, \mathrm{p}<0.01)$, incremental exploitation $(\beta=0.005, \mathrm{p}<0.01)$ and repetitive exploitation $(\beta=0.02, \mathrm{p}<0.01)$; however, this effect does not seem stronger than other predictors in the model. As we expected about control variables, there is a positive and significant effect of cooperation, training, internal sources of information, and acquisition of equipment, machinery or software. In Model 4, results indicate a negative impact on ambidexterity for companies from Peru and Ecuadorwith the effect on repetitive exploitation stronger than the effect on exploration and incremental exploitation.

Overall, the analysis provides various interesting outcomes. First, Hypothesis 1 to 4 are supported in regression analysis. Regarding results, it is possible to consider the effect of country variables on organizational ambidexterity: the direct impact of GDP per capita and dummies of each country.

On the other hand, results provide support for Hypothesis 4 to 8, regarding the impact of absorptive capacity on organizational ambidexterity. Additionally, Hypothesis 9 is supported by exploitation innovation and exploration innovation, which means that when companies work with existing and new products, there is a complementary effect of strategic and operational absorptive capacity. 


\section{Discussion, implications and limitations}

This study contributes to the existing investigation of organizational ambidexterity in several ways. It provides a more in-depth examination of the determinants of organizational ambidexterity in emerging economies, specifically, Latin American companies; introducing va- luable information about an under-researched region and contrasting to traditional literature which frequently focuses only on developed countries. This contribution is seemed crucial, when the most of Latin American countries develop incremental innovation with little or no impact on international markets, mostly based on imitation and technology transfer (Crespi \& Zuñiga, 2012).

Table 3 Linear Regression Analysis

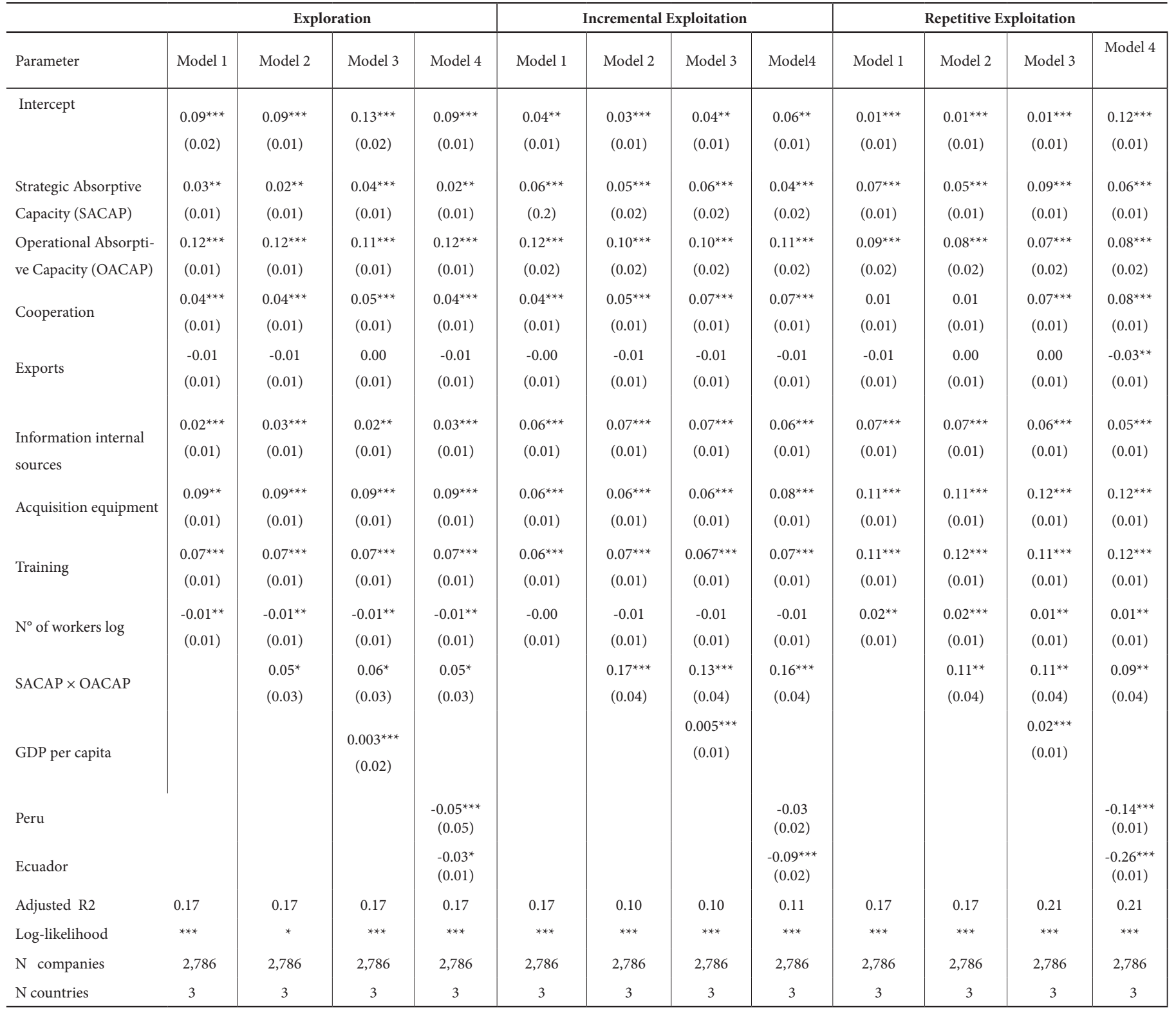

${ }^{*} \mathrm{p}<0.1 ;{ }^{* *} \mathrm{p}<0.05 ;{ }^{* *} \mathrm{p}<0.01$ 


\subsection{Implications to theory}

First, based on findings of Diaz-Molina (2018) and Piao and Zajac (Piao and Zajac,2016), the study confirms the importance to measure ambidexterity in a multidimensional perspective, considering that exploration dimension refers to radical innovation. Meanwhile, exploitation could be incremental as incremental innovation, or repetitive as operational efficiency. Most studies have analyzed ambidexterity through a dichotomic definition - exploration versus exploitation-, but this new approach comprehends the inherent complexity of an ambidextrous firm.

Second, this research provides insights into the direct effect of country environment on organizational ambidexterity. A limited number of researches has examined this relation, focusing in the mediator role of environment in the effect of ambidexterity on firm performance (Auh and Menguc, 2005; Jansen et al., 2006; Simsek, 2009). According to this, findings of our regression analysis show that country variables such as GDP per capita impact exploration and exploitation ability, supported our hypotheses about the positive influence of better economic and political situation of each country: if companies face particular contingencies created by each country, certain o stable conditions could impulse firms' strategies for innovative activities.

Third, it is possible to recognize that strategic and operational absorptive capacity has a positive and significant effect on ambidexterity, providing a better understanding of the ability of a firm to recognize, assimilate, and apply new knowledge for generating new competitive advantages. Besides, it is possible to confirm the findings of Diaz-Molina (2018) in emerging economies, observing that the effect of the operational dimension is stronger than strategic dimension aspect. Therefore, it seems that the skill of a firm's internal units to acquire and transform external information is more important than the strategy of reaching these external sources.

Additionally, companies conduct innovation knowledge separately from operational or efficiency best practices. However, the study confirms that the simultaneous application of both types of knowledge contributes positively to the exploration, incremental exploitation and repetitive exploitation within the firm. This finding will allow management to become more successful in its overall innovative efforts.

Regarding control variables, it is possible to observe a positive effect of training, cooperation, internal sources of information; and acquisition of equipment, which is coherent with literature in developed economies.

\subsection{Practical implications}

Our findings suggest several important managerial implications. Managers tend to treat innovation knowledge separately from operational or efficiency best practices. This study shows that the simultaneous application of both types of knowledge contributes positively to the radical and incremental innovation within the firm. This finding will allow management to become more successful in its overall innovative efforts.
Also, managers should prioritize investments in the acquisition, assimilation, and transformation of knowledge; acquiring knowledge internally through cross-functional work and frequent interactions with other departments, or externally, across a range of stakeholders including customers, suppliers, and trade partners (Patel et al.,2012). The key is to develop organizational learning capabilities to achieve competitive advantages.

The findings of this study is coherent with Heredia Pérez et al (2019), Latin American managers should develop the capacity to combine exploration and exploitation, because ambidextrous firms tend to outperform other in uncertain environment. Indeed, these authors recommended combine internal and external resources in environment of low institutional quality; meanwhile in positive institutional environment firms are able to be ambidextrous without a greater dependence on external cooperation.

\subsection{Policy implications}

Finally, the findings support the promotion of innovation programs in Latin America, especially thosefocused on the development of innovation knowledge and operational best practices. Indeed, legislation that incentivize $R \& D$ and innovation at the firm level has proven very effective The effect of tax incentives in $R \& D$ and innovation $(R \& D+i)$ has been extensively studied, and there is evidence that $1 \%$ increment in private $\mathrm{R} \& \mathrm{D}+\mathrm{I}$ expenditure increases a country's productivity growth by $0.13 \%$ (Guellec \& van Pottelsberghe de la Potterie, 2002).

\subsection{Limitations and future research directions}

Despite the positive results of this study, there are several limitations on the findings which are related to the absence of relevant control variables of the firm such as sector, age or size. This situation is due to the limited access to complete data sources for the three countries under study.

Future research is needed to acquire a comprehensive picture of organizational ambidexterity in Latin American companies. Additionally, it is interesting to investigate other relation that literature has postulated including the impact on performance of ambidexterity and absorptive capacity. On a final note, an effort should be made to improve the dataset of Latin American companies to include key descriptive variables and service companies.

\section{References}

Alvarez, R. \&. (2018). Innovation and entrepreneurship in Latin America: What do we know? What would we like to know? Estudios de Economía, 45(2), 157-171.

Alvarez, R., \& Grazzi, M. (2018). Innovation and entrepreneurship in Latin America: What do we know? What would we like to know? Estudios de Economía, 45(2), 157-171. doi:doi:10.4067/s071852862018000200157

Auh, S. \& Menguc, B. (2005). Balancing exploration and exploitation: The moderating role of competitive intensity. Journal of Business Research, 58, 1652-1661. doi:doi:10.1016/j.jbusres.2004.11.007 
Autry, C.W., Grawe, S.J., Daugherty, P.J., Richey, R.G. (2010). The effects of technological turbulence and breadth on supply chain technology and adoption. Journal of Operations Management, 28, 522536. doi:doi.org/10.1016/j.jom.2010.03.001

Barney, J. (1991). Firm resources and sustained competitive advantage. Journal of Management, 17, 99-120. doi:10.1016/s07423322(00)17018-4

Chen, J., Chen, Y. \& Vanhaverbeke, W. (2011). The influence of scope, depth and orientation of external technology sources on the innovative performance of Chinese firms. Technovation, 31, 362-373. doi:10.1016/j.technovation.2011.03.002

Cohen, W. M., \& Levinthal, D. A. (1990). Absorptive capacity: A new perspective on learning and innovation. Administrative Science Quarterly, 35(1), 128-152. doi:doi.org/10.2307/2393553

Corrado, C., Haskel, J. \& C. Jona-Lasinio. (2011). Productivity Growth, Intangible Assets and ICT: Some International Evidence. European Commission.

Crespi G.A., Tacsir E. \& Vargas, F. (2016). Innovation Dynamics and Productivity: Evidence for Latin America. En M. \&. Grazzi, Firm Innovation and Productivity in Latin America and the Caribbean: The Engine of Economic Development (págs. 37-71). Inter-American Development Bank. doi:10.1057/978-1-349-58151-1_2

Crespi, G. \& Zuñiga, P. (2012). Innovation and Productivity: Evidence from Six Latin American Countries. World Development, 40(2), 273-290. doi:10.2139/ssrn.1818752

Datta, A. (2012). IT-based knowledge capability and commercialization of innovations: Modeling the impacts of ambidexterity and absorptive capacity. International Journal of Knowledge Management, 8(3), 83-97. doi:10.4018/jkm.2012070105

Díaz-Molina, I. (2018). The Role of Strategic and Operational Absorptive Capacity in Organizational Ambidexterity. Engaged Management Scholarship Conference. Philadelphia. doi:10.2139/ssrn.3235526

Eustace, C. (2000). The Intangible Economy: Impact and Policy Issues. En Report of the European High Level Expert Group on the Intangible Economy . European Commission.

Field, A. (2013). Discovering statistics using IBM SPSS. Sage.

$\mathrm{s}$

Geldes, C., Felzensztein, C., Palacios, J.,. (2017). Technological and non-technological innovations, performance and propensity to innovate across industries: The case of an emerging economy. Ind. Mark. Manag, 61, 55-66. doi:doi.org/10.1016/j.indmarman.2016.10.010

Gibson, C. \& Birkinshaw, J. (2004). The antecedents, consequences, and ediating role of organizational ambidexterity. Academy of Management Journal, 47, 209-226. doi:10.5465/20159573
Guellec, D., \& van Pottelsberghe de la Potterie, B. (2002). R\&D and productivity growth. OECD Economic Studies, 2001(2), 103-126.

Gupta, A. K., Smith, K. G., \& Shalley, C. E. (2006). The interplay between exploration and exploitation. The Academy of Management Journal, 49(4), 693-706. doi:10.5465/amj.2006.22083026

Hall, R., \& C. Jones. (1999). Why Do Some Countries Produce so Much More Output Per Worker Than Others? The Quarterly Journal of Economics, 114(1), 83-116. doi:10.3386/w6564

Han, M. \& Celly, N. (2008). Strategic ambidexterity and performance in international new ventures. Canadian Journal of Administrative Sciences, 25, 335-349. doi:10.1002/cjas.84

Harris, R. \& Lee, T. (s.f.). Absorptive capacity in New Zealand firms: Measurement and importance. Motu Working Paper, 18(1). doi:10.29310/wp.2018.01

Haskel J. (2015). Understanding innovation better: an intangible investment approach. Asia-Pacific Journal of Accounting \& Economics, 22, 13-23. doi:10.1080/16081625.2015.1010268

Heredia Pérez, J., Geldes, C.,Kunc, M. \& Flores, A. (2019). New approach to the innovation process in emerging economies: The manufacturing sector case in Chile and Peru. Technovation(79), 35-55. doi:https://doi.org/10.1016/j.technovation.2018.02.012

Jansen, J. J., Van den Bosch, F. A. \& Volberda, H. W. (2006). Exploratory innovation, exploitative innovation, and performance: effects of organizational antecedents and environmental moderators. Management Science, 52, 1661-74. doi:10.1287/mnsc.1060.0576

Jansen, P., Tempelaar, M., van den Bosch, F. \& Volberda, H. (2009). Structural Differentiation and Ambidexterity: The Mediating Role of Integration Mechanisms. 20(4), 797-811. doi:10.1287/orsc.1080.0415

Lane, P.J., Salk, J.E. \& Lyles, M.A. (2001). Absorptive Capacity, Learning, and Performance in International Joint Ventures. Strategic Management Journal, 22, 1139-1161. doi:10.1002/smj.206

Laursen, K. \& Salter,A. (2006). Open for innovation: the role of openness in explaining innovative performance among UK manufacturing firms. Strategic Management Journal, 27(2), 131-150. doi:10.1002/smj.507

Lederman, D. (2010). An international multilevel analysis of product innovation. Journal of International Business Studies, 41(4), 606-619. doi:10.1057/jibs.2009.30

Lee, R. Ö. (2015). Introduction to the special issue on "innovation in and from emerging economies". Industrial Marketing Management, 50, 16-17. doi:10.1016/j.indmarman.2015.07.005

Levinthal, D. A., \& March, J. G. (1993). The myopia of learning. Strategic Management Journal, 14(2), 95-112. 
Lichtenthaler, U. (2009). Absorptive capacity, environmental turbulence, and the complementarity of organizational learning processes. The Academy of Management Journal, 52(4), 822-846. doi:10.5465/ amj.2009.43670902

Lin, H., Zeng, S., Liu, H., \& Li, C. (2016). How do intermediaries drive corporate innovation? A moderated mediating examination. Journal of Business Research, 69(11), 4831-4836. doi:10.1016/j.jbusres.2016.04.039

March, J. G. (1991). Exploration and exploitation in organizational learning. Organization Science, 2(1), 71-87. doi:10.1287/orsc.2.1.71 Netter, J., Wasserman, W., \& Kutner, M. (1990). Applied linear statistical models. irwin inc.

O’Reilly, C. \& Tushman, M. (2007). Ambidexterity as a dynamic capability: Resolving the innovator's dilemma. Research in Organizational Behavior, 28, 185-206. doi:10.2139/ssrn.978493

OECD. (1997). The measurement of scientific and technological activities: Proposed guidelines for collecting and interpreting technological innovation data. Oslo manual OECD. doi:10.1787/9789264192263-en

O’Reilly, C., \& Tushman, M. (2013). Organizational ambidexterity: Past, present and future. The Academy of Management Perspectives, 27(4). doi:10.5465/amp.2013.0025

Patel, P. C., Terjesen, S., \& Li, D. (2012). Enhancing effects of manufacturing flexibility through operational absorptive capacity and operational ambidexterity. Journal of Operations Management, 30(3), 201-220. doi:10.1016/j.jom.2011.10.004

Piao, M., \& Zajac, E. J. (2016). How exploitation impedes and impels exploration: Theory and evidence. Strategic Management Journal, 37(7), 1431-1447. doi:10.1002/smj.2402

Rouvinen, P. (2002). R\&D-Productivity Dynamics: Causality, Lags, and Dry Holes. Journal of Applied Economics, 1, 123-156. doi:10.1080 /15140326.2002.12040573

Sidhu, J. S., Commandeur, H. R. \& Volberda, H. W. (2007). The multifaceted nature of exploration and exploitation: value of supply, demand, and spatial search for innovation. Organization Science, 18, 20-38. doi:10.1287/orsc.1060.0212
Siggelkow, N. \& Levinthal, D. (2003). Temporarily divide to conquer: Centralized, decentralized, and reintegrated organizational approaches to exploration and adaptation. Organization Science,, 14, 650669. doi:10.1287/orsc.14.6.650.24870

Simsek ,Z. (2009). Organizational Ambidexterity: Towards a Multilevel Understanding. Journal of Management Studies, 46(4), 597-624. doi:10.1111/j.1467-6486.2009.00828.x

Tu, Q., Vonderembse, M.A., Ragu-Nathan, T.S., Sharkey, T.W. (2006). Absorptive capacity: enhancing the assimilation of time-based manufacturing practices. Journal of Operations Management, 24(5), 692710. doi:10.1016/j.jom.2005.05.004

van Wijk, R., Jansen, J. J. P., Van Den Bosch, F. A. J., \& Volberda. (2012). How firms shape knowledge to explore and exploit: A study of knowledge flows, knowledge stocks and innovative performance across units. Technology Analysis \& Strategic Management, 24(9), 929950. doi:10.1080/09537325.2012.718666

Venkatraman, N., Lee, C. \& Iyer, B. (2006). Strategic ambidexterity and sales growth: A longitudinal test in the software sector. Annual Meetings of the Academy of Management. Honolulu, Hawaii.

Vermeulen, F., \& Barkema, H. (2001). Learning through acquisitions. Academy of Management Journal, 44, 457-478. doi:10.5465/3069364

Yan, M., Yu, Y., \& Dong, X. (2016). Contributive roles of multilevel organizational learning for the evolution of organizational ambidexterity. Information Technology \& People,, 29(3), 647-667. doi:10.1108/ itp-04-2015-0079

Zacharia, Z.G., Nix, N.W., Lusch, R.F. (2011). Capabilities that enhance outcomes of an episodic supply chain collaboration. Journal of operations Management, 29(6), 591-603. doi:10.1016/j.jom.2011.02.001

Zahler, A., Goya, D., and Caamaño, M. (2018). The Role of Obstacles to Innovation. Working Paper Series Inter-American Development Bank. doi:10.18235/0001505

Zahra, S. A., \& George, G. (2002). Absorptive capacity: A review, reconceptualization, and extension. The Academy of Management Review, 25(2), 185-203. doi:10.5465/amr.2002.6587995 
